\title{
Marcel Arbeit and M. Thomas Inge, eds., The (Un)Popular South
}

Olomouc, Palacký University, 2011

\section{Marie Liénard-Yeterian}

\section{(2) OpenEdition}

\section{Journals}

Electronic version

URL: https://journals.openedition.org/transatlantica/6710

DOI: $10.4000 /$ transatlantica. 6710

ISSN: 1765-2766

\section{Publisher}

Association française d'Etudes Américaines (AFEA)

Printed version

Date of publication: 31 December 2013

\section{Electronic reference}

Marie Liénard-Yeterian, "Marcel Arbeit and M. Thomas Inge, eds., The (Un)Popular South", Transatlantica [Online], 2 | 2013, Online since 20 December 2019, connection on 31 January 2023. URL: http:// journals.openedition.org/transatlantica/6710 ; DOI: https://doi.org/10.4000/transatlantica.6710

This text was automatically generated on 31 January 2023.

\section{(c) (i) (3) $\Theta$}

Creative Commons - Attribution-NonCommercial-NoDerivatives 4.0 International - CC BY-NC-ND 4.0 https://creativecommons.org/licenses/by-nc-nd/4.0/ 


\title{
Marcel Arbeit and M. Thomas Inge, eds., The (Un)Popular South
}

Olomouc, Palacký University, 2011

\author{
Marie Liénard-Yeterian
}

\section{REFERENCES}

ARBEIT Marcel and M. Thomas INGE, eds., The (Un)Popular South, Olomouc, Palacký University, 2012, 222 pages, ISBN 978-80-244-2888-8.

1 The eleven articles included in the volume are the proceedings of the Southern Studies Biennial Conference held at Palacký University in September 2007. They offer many thought-provoking insights into the way the South has been either idealized or demonized. They cover a wide range of Southern issues (slavery, miscegenation, identity) and time periods (such as the Civil War and the civil rights movement) through the exploration of both literary and filmic media. This brilliant collection deals with both canonical and more contemporary writers, and tutors the reader (scholar and amateur) into thinking about what makes Southern fiction different today.

Marcel Arbeit's introduction titled "Southern (Un)Popularities" maps out the way the South has been seen as both a popular and unpopular place. Arbeit underlines "the durability of the cultural concept of the South" (9), and presents the paradox that "the South"-itself a "fluid term"- has often been seen as "popular" despite, and sometimes even because of, its "unpopular" ("despicable") practices. He also deals with the topic of Southern writers who were first recognized abroad because their fiction disturbed conventional images at home. The book is then organized into four parts. The first part, titled "The Unpopular South of Slavery, Secession, and Segregation", includes two essays. Waldemar Zacharasiewicz, in his contribution entitled "Southern Society Disliked or Misunderstood: Perspectives of Visitors to the Nineteenth-Century South from Outside," presents the way the antebellum South was perceived by outside visitors (northerners and foreigners). Their views were ambivalent as they both praised 
certain aspects of Southern life but remained very critical of the plantation system and slavery. Owen Robinson's "North to the South: New Orleanian Identities in the Work of W. Adolphe Roberts and George Washington Cable" focuses on the particular situation of New Orleans as what he calls "a fascinating paradigm of the problems of regional codification" (45); he uses as case studies non-Creole Cable's nineteenth-century tales of Creole life and the twentieth-century Jamaican writer's novels which dramatize the insider-outsider dynamic. The second part, entitled "Stains of the Past in Southern Fiction: Unpopular Making Popular," contains three articles that address the legacy of the past in Southern fiction. William Lazenbatt's "Intruder in a Time to Kill a Mockingbird: How the Courtroom Drama Makes the Unpopular South Popular," interestingly revisits three famous novels made even more popular by their filmic adaptations (William Faulkner's Intruder in the Dust, Harper Lee's To Kill a Mockingbird, John Grisham's A Time to Kill), and demonstrates how fiction and film rehearse Southern cultural stereotypes to stage the drama of race on trial. Pearl A. McHaney's article "Southern Erasures: Natasha Trethewey's Native Guard" takes up the issue of racerelated dimensions of Southern history by exploring recent attempts at exposing historical erasure, in particular through the Poet Laureate's 2007 collection. Jan Nordby Gretlund's “'Still there?': Encapsulated Prejudice in Today's Southern Fiction” discusses the way in which recent fiction by writers such as Percival Everett, Chris Offutt, and Steve Yarbrough processes the legacy of the past while voicing the particular dilemma of the Southern writer poised between acceptance and rejection. He raises a number of challenging issues to consider the place of old demons in Southern fiction today. Do contemporary writers deal with "the clay-eating and cross-burning Southern past" (99) or do they consider that the "stains" of past "sins" and "prejudices" have disappeared?

3 The third part titled "(Un)Popular Southern History Through (Un)Popular Southern Writers," reprises issues of the dialectic popular/unpopular through analysis of the fiction of Shirley Ann Grau by Gérald Préher in a piece titled "Shirley Ann Grau's The Keepers of the House: An Unpopular Pulitzer-Winning Novel" and Barry Hannah by Noel Polk in "Even Mississippi: Legending in Barry Hannah's Bats Out of Hell." Both scholars show how these two works orchestrate a return of the Southern repressed by dealing with unpleasant (unpopular) and controversial issues such as miscegenation and interracial marriage, the Klan, the rednecks or the memory of the Civil War. The final part of the book, "Unpopular South in Popular Culture," widens the scope of the inquiry to include such diverse topics as myth, genre fiction (in particular fantasy) and animated film. Thomas Ærvold Bjerre's "The Wild West Visits Mississippi: (Mis)Using the Western Myth in Lewis Nordan's The Sharpshooter Blues," underlines that "the direct manifestation of the Western myth in the Deep South can be found in Southern novels" (157), and shows how Nordan's 1995 novel revisits and redefines the myth of the Frontier. Marcel Arbeit's essay "Popular Fiction on (Un)Popular Southern Themes: Fred Chappell's Fantastic Stories" contextualizes the Appalachian writer's use of the fantastic to explore the multifaceted and contradictory dimensions of his native South. The last article, M. Thomas Inge's "Walt Disney's Racial Dilemma in Song of the South," deals with the complex issue of the way the South is represented and staged in film by offering a close reading of Walt Disney's 1946 adaptation of the Uncle Remus stories by Joel Chandler Harris. Inge analyses Disney's handling and use of certain Southern and African American themes and images, and studies the impact of the feature on the way the South is viewed across the world. 
4 The overall volume helps us envisage recent developments in fiction, thematic and formal, with a view to exploring the way contemporary authors write about the South while tracking down the stigmas of the past still visible in the Southern psyche. The emphasis on the individual character and what Gretlund calls "the situatedness in place and community" (106) seems to have replaced the exploration of historical sins in the Southern imagination. Last but not least, the essays invite us to consider how the traditional handling of borders and roots by Southern writers includes a discussion of the way the subject negotiates the individual from the collective, thus throwing new light on contemporary discussions of agency.

INDEX

Subjects: Recensions

\section{AUTHORS}

MARIE LIÉNARD-YETERIAN

Université de Nice - Sophia Antipolis 